\title{
Positive Emotion Skills at Work: Intervention To Increase Well-Being of Working Mothers in Pmi Central Java
}

\author{
Frieda, N.R.H, Anggun Resdasari Prasetyo, Ika Zenita Ratnaningsih, Jati Ariati, Unika \\ Prihatsanti, Nailul Fauziah, Erin Ratna Kustanti
}

Faculty of Psychology, Diponegoro University, Indonesia

anggun.resdasari@gmail.com

\begin{abstract}
This study aims to determine the effect of Positive Emotion Skills at Work to increase well-being in working mothers in PMI Central Java. The experimental method used was a quasi-experiment that was randomized pretest-posttest control group design. The research subjects were 24 persons with characteristics: Working woman aged between 22 - 54 years old, and at least one year working. Subjects were divided into two groups, namely the experimental group and the control group. The measuring tool used was the well-being scale of Diener. Measurements were given in pre-test and post-test. Based on the results of Mann Whitney $U$ analysis obtained value $p=0.219 ; P>0.05$. The results explain that there is no difference in post test scores in the control group and experimental group. The rejected hypothesis can be found that both the pretest and postes well-being scores on in the control group and the experimental group indicate that they already have a good wellbeing so that this training is a method of maintaining their wellbeing. This well-known WB indicator can be known that PMI is one of the organizations working in the field of humanity and social, so that the individuals involved in working in PMI are individuals willing to work voluntarily
\end{abstract}

Keywords: Positive emotion skills at work, wellbeing, working mother, PMI.

\section{INTRODUCTION}

Finding a job is everyone's basic need, for both men and women. Working or having a profession has established various meanings for everybody. Based on that, nowadays, it is common for Indonesian, especially women, who work after graduated from school or from colleague. Their reason to find a job is not only for making the ends meet but also for actualizing themselves, applying their knowledge from their formal school or non-formal education institution (Permatasari 2010). For women, especially those who already being mothers, working has resulted in several effects, both positive and negative. For working mothers, they believe that working can bring their pride to the next level and support their daily need so that they become more independent. Married women have many roles such as being a wife, a mother, and a female employee. Junita (2011) stated that working women tend to have a wider and varied environment, so that they will be more open-minded.

One of the institutions having many female workers is Indonesian Red Cross (Palang Merah Indonesia/PMI). PMI is an organization in humanism and social, that works voluntarily. Every year, PMI holds several events like early warning for disasters, blood donors, health service for community and others which aim to help the community. Working mothers in PMI is characterized as social workers that have always been the main focus and expected to be professional in handling clients and do the jobs professionally. Social workers are expected to be creative and responsible. Various job expectations and work pressure are potential to create boring situation and put some burdens on the workers. This might cause problems to work environment, to the clients, colleagues, supervisors and family (Yusuf, 2011).

Job descriptions in PMI require employees with good well-being, related to the role as workers in PMI and as mothers in the family. Well-being condition has been an important factor because PMI focuses in helping others. According to Rahmat (Jangkung, 2013), helping others is one of the factors that triggers happiness. Positive feelings that appear after helping others can trigger to have the attitude of helping and positive feedback from what has been given will make happiness more meaningful. The feeling of happy and peaceful after doing good deeds is in line with religious requirements and provides self-satisfaction for an individual.
Happiness is gained from various things; one of them is sharing which becomes self-satisfaction of individuals because of the ability to help others. Seligman (2005) believes that positive feelings will initiate an individual to do positive actions like building good relations with surroundings, having positive and optimistic feelings, having good spiritual health, establishing harmonious family, being able to help others, living in harmony with neighbors, being able to be thankful and respecting others. Those aspects lead to one's real happiness.

According to Fromm (in Schultz, 2005), well-being is an integral part of life and a result of life that relates to productive orientations. Happiness is not merely a positive feeling or situation but a condition that develops an organism, resulting in more lifestyle, physical health and fulfillment of one's potential. Productive individuals are happy individuals. A feeling of happiness is an evidence of successful individual in life. Meanwhile, Seligman (2005) defines happiness as a concept referring to positive emotions experienced by individuals and positive activities without negative feelings, for example, when individuals are involved in their favorite activities. Positive emotions related to past, present, and future are experienced by those individuals. Bastaman (2008) stated that individuals experience happy life when they do many activities resulting in beneficial matters, having clear life objectives, improving the way of thinking and positive actions, and actively developing their self-potential which includes physical, mental, social, and spiritual potentials. Other characteristics of happy individuals are healthy personality traits which are characterized by healthy body, smart brain, positive attitude, being firm, being gentle, strong belief, flexible in socializing with others, being thankful, and willing to help others to experience happiness at their level. Lyubomirsky (2007) stated that happiness is global and subjective assessment in examining oneself as happy or not. The statement was based on the opinion that happiness is measured from subjective criteria in individuals. Lyubomirsky also defined that an individual might experience unhappiness even though he is surrounded by comfort, love, and wealth. On the other hand, an individual might be happy although he experiences obstacles, tragedy, poverty, and less love. Those statements provide evidence that the source of happiness is personal and might be varied in individuals. 
Well-being is an important factor in an institution or organization because an increase in the workers' well-being results in positive impact for the company. Workers' wellbeing has a significant effects in cost efficiency related to workers" health (Danna \& Griffin, 1999), absenteeism and worker turnover (Spector, 1997), work performance and work satisfaction (Russel, 2008). Well-being in job and in family is resulted from individuals that are happy and apply happiness in their aspects of life. Every human desires to be happy, healthy and prosperous in their physical, social, and spiritual life. Well-being can be obtained through six aspects namely accepting the strengths and the weakness, being able to maintain good relationship with others, being independent, adapting to the surroundings, having the purposes of life and developing self-potentials (Ryff, 1989). Well-being is important for women especially for those having a role as mothers. Well-being describes a healthy mental state that influences other aspects of life. As a mother, psychological prosperity influences her belief in nurturing her children so that results in the increase of positive development of the children. Achieving the condition of well-being is every individual's dream, including working mothers. Yet, the efforts to provide solutions for problems experienced by those working mothers, especially to increase well-being have not enough yet, furthermore, the intervention based on positive psychology is still rarely found because for the time being, the therapy given are focused on personal after-effects such as trauma, wound, and physical disabilities (Selligman et all, 2006).

Wellbeing in working place and in family is discovered in individuals who are happy and enjoy happiness in their life. Each individual wishes for happy, healthy and prosperous life in all aspects, physically, socially, and spiritually. Working mothers play a bigger role since they have to balance their work and family life. Related to work-family balance, the balance means the ability to share time, attention and energy equally which results in satisfying results, or being able to accomplish the responsibilities at the office and at home satisfactorily. It is possible since a mother has the ability to have different roles and sets the priority. To achieve a balance in work and family life, wellbeing of working mothers should be grown and nurtured.

Related to problem formulation, the research proposed an intervention to improve wellbeing of working mothers. The intervention is based on positive psychology theory by designing and implementing Positive Emotion Skills at Work. The intervention of Positive Emotion Skills at Work was implemented by developing positive strength and fulfilling life with positive emotions and performing strength focus. Positive psychology intervention is focusing on optimism, hope, empowerment to obtain happiness in life. The efforts to establish positive emotions by implementing intervention based on positive psychology has been believed to provide positive effects to self-development as stated on a research by Fredrickson \& Branigan (2005). They believe that positive emotion has the ability to omit the effects destructive effects of negative emotions and to increase individual self-resilience. The finding is also supported by a research by Fredrickson \& Joiner (2002) which states that positive emotion is positively correlated to individual well-being (in Selligman et all, 2006).

\section{RESEARCH OBJECTIVE}

The research aims to define the effects of Positive Emotion Skills at Work to improve well-being in working mothers in PMI Central Java.

\section{METHODOLOGY}

The independent variable in the research was Positive Emotion Skills at Work and the dependent variable was wellbeing. The subjects of the research were working mothers consist of 25 persons characterized by: working mothers aged 22-54 year old and have been working in PMI Central Java for minimum a year. The subjects were divided into two groups, the experimental group and the control group; each group consists of 12 persons.

The method of the research was a quasi-experimental design using the pretest-posttest control group design, which consists of the experimental group and the control group. The experimental group was treated by Positive Emotion Skills at Work while the control group experienced no treatment. The experiment of pretest-posttest control gro design is formulated as follows:

$$
\begin{array}{ll}
\mathrm{KE} & \mathrm{O} 1(\mathrm{X}) \longrightarrow \mathrm{O} 1 \\
\mathrm{KK} & \mathrm{O} 2(-) \longrightarrow \mathrm{O} 2
\end{array}
$$

Figure 1.1 Pretest-posttest control group design

$\mathrm{KE}$ is the experimental group

$\mathrm{KK}$ is the control group $\mathrm{X}$ is the intervention, or Positive Emotion Skills at Work

(-) means that no intervention involved.

The wellbeing of the subject was measured by wellbeing short version scale by Diener et al (2010), where $\alpha=0,8666$. The wellbeing scale consists of 8 items with four options range from Strongly Agree to Strongly Disagree. Some of the items are "I maintain beneficial social relationship" and "I am involved and interested in my daily activities". The measurement tool was applied in both pretest and posttest of the experimental group and control group.

The intervention given to the experimental group was Positive Emotion Skills at Work based on Positive psychotherapy. According to Selligman et al (2006) positive psychotherapy is a focused therapy to establish positive emotion, character strength, and meaningfulness through establishing pleasant life, engaged live and pursuit of meaning to overcome clinical problems and negative things. The training was held in four sessions. The first session was opening, the second was exploration, the third was understanding and the fourth was contemplation.

\begin{tabular}{|l|l|}
\hline Activities & $\begin{array}{l}\text { Introducing team members to participants, ice } \\
\text { breaking, training description, training contract, and } \\
\text { discussion on expectations during training }\end{array}$ \\
\hline Duration & 20 minutes \\
\hline Equipment & $\begin{array}{l}\text { Name tag, training contract sheet, expectation sheet, } \\
\text { ice breaking equipment, laptop, LCD projector, } \\
\text { stationery. }\end{array}$ \\
\hline Objectives & $\begin{array}{l}\text { Building the rapport between trainer team and } \\
\text { participants } \\
\text { - Participants would be able to understand the } \\
\text { objectives of the training } \\
\text { Motivating participants to take part in the training } \\
\text { seriously. }\end{array}$ \\
\hline
\end{tabular}

\section{SESSION 1 OPENING}

The opening session is aimed to provide initial knowledge to the participants. The session consists of introduction, ice breaking, training description, training contract, and discussion on expectations during training.

Procedure:

1. Trainer starts the training by motivating the participants and praying together

2. Trainer introduces him/herself and the members of the team. Trainer also provides opportunity for the 
participants to introduce themselves through ice breaking activities.

3. Trainer conveys the objectives of the training including the activities for 10 minutes.

4. Trainer discusses contract and expectation of the training for 5 minutes.

\begin{tabular}{|l|l|}
\hline Activity & $\begin{array}{l}\text { Discussion 1 } \\
\text { Discussion 2 }\end{array}$ \\
\hline Duration & 90 minutes \\
\hline Equipment & Stationary, worksheet 1, worksheet 2, plano paper \\
\hline Purpose & $\begin{array}{l}\text { To identify problems, explore experiences } \\
\text { (positive and negative) of participants related to } \\
\text { multiple roles as working women }\end{array}$ \\
\hline
\end{tabular}

\section{SESSION 2 EXPLORATION}

During the exploration session, participants were asked to identify the problems experienced during their role as PMI worker, to explore the process of adjustment, the wellbeing condition of each participant

Procedure:

1. Trainer started the second session by dividing the participants into 5 groups. Each group was accompanied by a facilitator.

2. The facilitator divided the first worksheet to the participants and accompanied the participants in doing the assignment on small group. Before started to work, the facilitator gave the instructions "In this worksheet, you are required to complete the sentence that has been available for 10 minutes. You are free to write whatever you want to express the feelings and thoughts that you have. There is no right answer and no wrong answer. It aims to express your feelings as a woman with multiple roles." ("Pada lembar kerja ini, anda diminta melengkapi kalimat yang telah tersedia selama 10 menit. Anda bebas menuliskan apapun yang ingin anda ungkapkan sesuai dengan perasaan dan pikiran yang anda miliki. Tidak ada jawaban benar dan tidak ada jawaban yang salah. Hal ini bertujuan untuk mengungkapkan perasaan anda sebagai wanita dengan peran ganda.").

3. Trainer asked participants to join the big group again. Trainer guided participants to discuss "discussions 1" that has been done. Trainer then allowed participants to express their feelings and participate in discussions. During the discussion, the trainer accompanied the participants in revealing the important points in this discussion, such as the problems women faced with their multiple roles and expectations of work and their families. This activity lasted for 30 minutes.

4. Trainer asked participants to come back in small groups and do "discussion 2. The facilitator guided the participants to the discussion 2. The facilitator gave the instructions "In this worksheet, you are asked to answer questions that have been available for 10 minutes. You are free to write whatever you want to express related to the feelings, thoughts, and experiences you have. There is no right answer and no wrong answer. It aims to explore your feelings and thoughts about unhappy experiences and how you react to them." (Pada lembar kerja ini, anda dimintamenjawab pertanyaan yang telah tersedia selama 10 menit. Anda bebas menuliskan apapun yang ingin anda ungkapkan sesuai dengan perasaan, pikiran, dan pengalaman yang anda miliki. Tidak ada jawaban benar dan tidak ada jawaban yang salah. Hal ini bertujuan untuk menggali perasaan dan pemikiran anda terkait pengalaman yang tidak membahagiakan dan bagaimana anda menyikapinya".)

5. Trainer asked participants to join the big group again. Trainer guided participants to discuss discussions 2 that has been done. Trainers allowed participants to express their feelings and participate in discussions. During the discussion, the trainer accompanied the participants to reveal the important points in this discussion, such as the meaning of positive and negative experiences as women with multiple roles. This activity lasted for 30 minutes.

6. Trainer summarized the results of the discussion and closed the session with the applause and greetings of "Alhamdulillah, I am grateful and happy !!!." (Alhamdulillah, saya bersyukur dan bahagia !!!). This activity lasted for 10 minutes.

\begin{tabular}{|l|l|}
\hline Activity & PPT material, discussion \\
\hline Duration & 45 minutes \\
\hline Equipment & Stationary, LCD, Laptop, worksheet \\
\hline Purpose & $\begin{array}{l}\text { To understand the needs and } \\
\text { principles also integrate between } \\
\text { positive and negative experiences }\end{array}$ \\
\hline
\end{tabular}

\section{SESSION 3 UNDERSTANDING}

The third session is the understanding. This session contains the material explanations by trainers about working women, roles, dynamics and ways of adjustment. This session aims to understand the needs and values/ principles of the participants, integrate between positive and negative experiences, start to develop the positive emotions.

Procedure:

1. Trainers opened the session by doing ice breaking

2. Trainers invited the participants to sit in circles and began delivering the materials. The steps are as follows:

- The trainer communicates the purpose of the session: that is the participants of discussion can share their experiences as multiple roles women. Also the attitude in responding to her experience.

- Trainer conveys the material about happiness: that is, about the meaning of a positive experience. Trainers direct participants to start developing the positive effects.

\begin{tabular}{|l|l|}
\hline Activity & Displaying slides about emotion management, relaxation \\
\hline Duration & $45-60$ minutes \\
\hline Equipment & Stationary, LCD, Laptop, worksheet, white board \\
\hline Purpose & $\begin{array}{l}\text { To be more grateful and happy for the participants } \\
\text { To increase the positive effects and decrease the negative } \\
\text { effects }\end{array}$ \\
\hline
\end{tabular}

\section{SESSION 4 CONTEMPLATION}

The fourth session is the stage of taking action to bring about gratitude. In this session participants can plan for future plans and act more with new behaviors. Afterwards, in this session participants are also given relaxation aimed at reducing negative effects and increasing positive effects.

Procedure:

1. The facilitator gives task of "Be grateful and happiness woman" for 15 minutes. In that task, participants were asked to write a plan strategy to be a grateful and happy woman.

2. The facilitator and participants jointly discussed the outcome of the task, then provided verbal reinforcement of the behavior that supports the strategy to become a grateful and happy woman 
3. Trainer provided relaxation for 15 minutes.

\section{RESULT AND DISCUSSION}

Based on the result of the research, the descriptive statistic can be seen on the following table:

Table 1.1 Wellbeing Score

Table 1.2. Descriptive Data of Age and Working Period

\begin{tabular}{|c|c|c|c|c|c|c|}
\hline & \multicolumn{6}{|c|}{ Descriptive Statistics } \\
\hline & & $\mathrm{N}$ & Minimum & Maximum & Mean & Std. Deviation \\
\hline KE_pretest & & 12 & 22 & 28 & 24.58 & 1.676 \\
\hline KE_postest & & 12 & 23 & 29 & 25.58 & 2.429 \\
\hline KK_pretest & & 12 & 23 & 27 & 24.33 & 1.497 \\
\hline KK_postest & & 12 & 22 & 29 & 24.33 & 2.015 \\
\hline $\begin{array}{l}\text { Valid } \\
\text { (listwise) }\end{array}$ & & 12 & & & & \\
\hline
\end{tabular}

\begin{tabular}{|c|c|c|c|}
\hline Group & & KE & KK \\
\hline \multirow{3}{*}{ Age } & & & \\
\cline { 2 - 4 } & Mean & 40 & 45,66 \\
\cline { 2 - 4 } & Min & 29 & 22 \\
\cline { 2 - 4 } & Max & 52 & 55 \\
\hline \multirow{3}{*}{$\begin{array}{c}\text { Working } \\
\text { period }\end{array}$} & Mean & 14,77 & 23,5 \\
\cline { 2 - 4 } & Min & 2 & 1 \\
\cline { 2 - 4 } & Max & 30 & 34 \\
\cline { 2 - 4 } & & & \\
\hline
\end{tabular}

From the descriptive statistics table above, it can be seen that the number of subjects in the experimental group and the control group are the same, i.e. each of 12 people. The table shows that on the pretest and posttest, the mean on KE and KK shows no significant difference.

The statistical techniques used in this study were nonparametric statistics using the U-Mann Whitney analysis. This analysis was used because the experimental design used would compare between the control group and the experimental group, as well as the initial pre-training measurement and re-measurement after the training. U-Mann Whitney analysis was chosen because the subjects were selected by non-random technique. The results of processing $\mathrm{U}-\mathrm{Mann}$ Whitney resulted in the value of $\mathrm{sig}=.551 ; \mathrm{p}>0.05$. The results explain that there is no difference in post test scores in the control group $(\mathrm{M}=24.33, \mathrm{SD}=2.015)$ and experimental group $(\mathrm{M}=25.58, \mathrm{SD}=2.429)$. This condition is also supported by the pre-test score in working mothers at PMI in the control group $(\mathrm{M}=24.33, \mathrm{SD}=1.497)$ and the experimental group $(\mathrm{M}=24.58, \mathrm{SD}=1.676), \mathrm{sig}=.843, \mathrm{p}$ $>.05$ shows that they already have a good well-being. This well-known PWB indicator can be known that the Indonesian Red Cross or often known as PMI is one of the humanitarian and social organizations, so that the individuals involved in working at PMI are individuals who are willing to work voluntarily. As explained by the results of research conducted by Iryana (2015) which explains that PMI officers have had altruism and relatively high level of happiness. Workers, who have true altruism like workers at PMI, work solely for the purpose of improving the welfare of others (giving happiness to someone as a result of help) (Myers, 2012). In addition, they can also cooperate well with others (cooperation), able to feel what others feel or empathy (sharing), willing to help to alleviate the burden of others (helping), always sharing and giving voluntarily (generosity). The whole aspect becomes part of the characteristics possessed by the subject.

Based on the analysis of pretest and posttest scores in the experimental group, basically there was the increasing movement of Wellbeing score although not significant, while in the control group did not change. With the increase of wellbeing score in the experimental group, basically the training of Positive Emotion at Work can be given to the subjects of working mothers, but with some improvement to internal validity. To determine the effectiveness of positive emotion at work implementation, both short and long term, it is necessary to re-research by using modules that have been compiled and fix the existing weaknesses by increasing the number of sessions, increasing the number of participants or applying to various job settings, adding measurement instruments, and performing post-training follow-up or selfmonitoring task assignments.

\section{CONCLUSION AND SUGGESTION}

From the result of the research, it can be concluded as follows:

1. The results of this research by using quantitative analysis can prove that there is no significant influence from the application of Emotion Positive Skills at Work toward the Well Being of working mother at PMI.

2. The pretest score of psychological well-being on working mothers at PMI in the control group and the experimental group showed that they already had good well-being.

3. Based on the analysis of pretest and posttest score in the experimental group, basically there was an increasing movement of WB score although it was not significant, while in the control group did not change. With the increase of WB score in the experimental group, then basically the given training on Positive Emotion at Work can be addressed to working mothers, but with some improvement to internal validity.

To determine the effectiveness of positive emotion at work implementation, both short and long term, it is necessary to re-research by using modules that have been compiled and fix the existing weaknesses, that is by increasing the number of sessions, increasing the number of participants or applying to various job settings, adding measurement instruments, and performing post-training follow-up or assigning self-monitoring task.

\section{REFERENCE}

Danna, K., \& Griffin, R.W. (1999). Health and well-being in the workplace: A review and synthesis of the literature. Journal of Management, 25, 3, 357-384

Diener, E., Wirtz, D., Tov, W., Kim-Prieto, C., Choi, D. W., Oishi, S., et al. (2010). New well-being measures: Short scales to assess flourishing and positive and negative feelings. Social Indicators Research, 97, 143-156. Fordyce, M. W. (1988). A review

Fredrickson, B. L., \& Branigan, C. (2005). Positive emotions broaden the scope of attention and thought-action repertoires. Cognition and Emotion, 19, 313-332.

Fredrickson, B. L., \& Joiner, T. (2002). Positive emotions trigger upward spirals toward emotional well-being. Psychological Science, 13,172-175

Iryana, I. (2015). Altruisme dengan Kebahagiaan pada Petugas PMI. Skripsi Tidak Dipublikasikan. Universitas Muhamadiyah Surakarta 
Jangkung, S. (2013). Dinamika Kebahagiaan Relawan Pusat Studi dan Layanan Difabel (PSLD) UIN Sunan Kalijaga Yogyakarta. Skripsi. Yogyakarta. Universitas Islam Negeri Sunan Kalijaga.

Junita, A. (2011). Konflik Peran Sebagai Salah Satu Pemicu Stres Kerja Wanita Karir. Jurnal Keuangan dan Bisnis, 3 (2), 93-110

Myers, D. G. (2012). Psikologi Sosial (Social Psychology). Jakarta : Salemba Humanika

Lyubomirsky, Sonja.(2007).The How of Happiness.London:Sphere

Permatasari, A.I. (2010). Konflik peran ganda ibu bekerja ditinjau dari tingkat ketabahan. Skripsi Tidak Dipublikasikan. Semarang. Universitas Katolik Soegijapranta Semarang

Russel, J. E. A. (2008). Promoting subjective well-being at work. Journal of Career Assessment, 16, 1, 117-131

Ryff, C.D. (1989). Happiness is everything, or is it? Exploration on the meaning of Psychological Well-Being. Journal of Personality and Social Psychology, 57(6), 1069-1081
Schultz, D., (2005). Theories of personality (5th ed). California: Brooks/Cole Publishing Company.

Seligman, M.E.P., Rashid, T., \& Parks, A.C. (2006). Positive psychotherapy. Journal American Psychologist. November 2006

Seligman, M. E. P. (2005). Menciptakan Kebahagiaan dengan Psikologi Positif (Authentic Happiness). Bandung : PT. Mizan Pustaka.

Spector, P. E. (1997). Job satisfaction: Application, assessment, causes, and consequences. California: SAGE Publications, Inc

Yusuf, H. Pengaruh Kondisi Organisasi Terhadap Kejenuhan Kerja Pekerja SosialYang Bekerja di Panti Sosial Penyandang Cacat di Indonesia. Jurnal Informasi, Vol. 16 No. 03 Tahun 2011. 